\title{
anemon
}

Muş Alparslan Üniversitesi Sosyal Bilimler Dergisi

Journal of Social Sciences of Muş Alparslan University

Yıl/Year: 2017 • Cilt/Volume: 5 • Sayı/Number: 3

ISSN: 2147-7655 • e-ISSN: 2149-4622

ÖZGÜN ARAŞTIRMA • ORIGINAL ARTICLE

\section{İran ve Türkiye Eğitim Sistemlerinin Amaçlarının Karşılaştırmalı Analizi a}

\author{
Doğan ÖZLÜK ${ }^{1, b}$ \\ ${ }^{1}$ Arş. Gör., Muş Alparslan Üniversitesi, Eğitim Fakültesi, Eğitim Bilimleri Bölümü, Muş-Türkiye \\ Başvuru tarihi: 16 Ocak 2017 Düzeltme tarihi: 22 Şubat 2017 Kabul tarihi: 01 Mart 2017
}

Öz

Türkiye ve İran, Ortadoğu'nun iki önemli ülkesi olarak tarihi, kültürel, siyasi, ekonomik ve coğrafi ilişkilere sahiptir. Her iki ülkenin benzer modernleşme ve Batılılaşma süreçlerinden geçmeleri iki ülkenin eğitim politikalarına da yansımıştır. Bu durumun bir sonucu olarak Batılılaşma eğilimi, iki ülkenin eğitim sistemini başta amaçlar olmak üzere yap1, yönetim ve finansman açısından etkilemiştir. $\mathrm{Bu}$ nedenle iki ülkenin eğitim sistemlerinin karşılaştırılmasının literatüre katkı sağlayacağı düşünülmektedir. Türkiye ve İran'ın eğitim sistemlerine bakıldığında birçok benzerliğin ve farklılı̆̆ın olduğu görülmektedir. Ancak siyasal rejimleri birbirinden çok farklı olmasına rağmen, her iki ülkenin eğitim sistemleri, tek tip insan yetiştirmeyi hedeflemeleri bakımından oldukça benzer amaçlara ve özelliklere sahiptir Bu çalışmanın amacı, tarihten bu yana güçlü ve dengeli ilişkiler kurmuş iki komşu ülke olan İran ve Türkiye'nin mevcut eğitim sistemlerinin amaçlarını karşılaştırmaktır. Araştırma genel olarak karşılaştırmalı eğitim çalışmaları doğrultusunda bir içeriğe sahip olup Türkiye ve İran eğitim sistemlerinin amaçlar açısından özellikleri, benzerlikleri ve farklılıkları tespit edilmiş, bulgular yorumlanmış ve çeşitli önerilerde bulunulmuştur.

\section{Anahtar Kelimeler}

Karşılaştırmalı Eğitim, Türkiye Eğitim Sisteminin Amaçları, İran Eğitim Sisteminin Amaçları

\footnotetext{
${ }^{a}$ Bu çalışma, 2016 yılında Gaziosmanpaşa Üniversitesi Eğitim Bilimleri Enstitüsü tarafından kabul edilen "İran ve Türkiye Eğitim Sistem/erinin Yapı ve Amaçlar Açısından Karşılaştırmalı Analizi" adlı Yüksek Lisans tezinden türetilmiştir.

b Sorumlu Yazar/Correspoding Author: Muş Alparslan Üniversitesi, Eğitim Fakültesi, Eğitim Bilimleri Bölümü, 49250, Muş /Türkiye.

e-posta: doganozluk@yahoo.com

doi: 10.18506/anemon.286057

URL: http://dergipark.gov.tr/anemon

Copyright @ 2013-2017 Muş Alparslan Üniversitesi
} 


\title{
Comparative Analysis of the Purposes of Education Systems in Iran and Turkey
}

\begin{abstract}
Turkey and Iran have historical, political economic and geographical relations as the two important countries of the Middle East. These ongoing relationships require the comparison of the educational systems of both countries. When we look at the education systems and status of the two countries, from demographics to schooling rates, from objectives to the structure it is possible to find serious similarities. There are differences to note as well. Despite the incompatibility between the political regimes of the two, they are similar in targeting to create a uniform and homogenous nation. Similar modernization processes in both countries have influenced the adaptation of similar educational policies and implications. As a result of that, the favour of westernization influenced the structure, objective, management and financing of education system in both countries. The purpose of this study is to compare the aims of the existing education systems of two neighboring countries Turkey and Iran that built a strong relationship. This research figures out the similarities and differences of Turkish and Iranian educational systems in structure and main purposes, interprets the findings and propose several suggestions.
\end{abstract}

\section{Keywords}

Comparative Education, The Aims of Turkish Educational System, The Aims of Iranian Educational System

\section{GIRIŞ̧}

İnsan ve toplumların etkileşim içerisinde oldukları bir gerçektir. Bu durum ülkeler için de geçerlidir. Günümüzde ise bu etkileşim çok daha yoğun yaşanmaktadır. Bu etkileşimin bir parçasını eğitim sistemleri oluşturmaktadır. Eğitim sistemlerinin benzerliklerini, farklılıklarını, etkileşimlerini ve etkileşim düzeylerini ele almak bakımından karşılaştırmalı eğitim, günümüzde oldukça önem arz etmektedir. Bir ülkenin eğitim sistemini sadece kendi iç dinamikleriyle ele almak, şüphesiz bazı verilerin ortaya konmasını sağlayacaktır. Ancak sadece iç dinamiklerle yetinmek eksik kalacaktır. Bu eksikliği gidermek açısından karşılaştırmalı eğitim oldukça işlevsel bir rol oynamaktadır.

Karşılaştırmalı eğitim, çeşitli ülkelerde eğitimle ilgili olguları analiz ederek, ülkelerin kendi eğitim sorunlarına çözüm yolları ararken geniş bir perspektifle hareket etmelerini sağlamaktadır. Karşılaştırmalı eğitimin temel amaçlarından biri, eğitimi etkileyen unsurların çeşitli ülkelerdeki gelişimini ve mevcut durumunu inceleyerek oluşturulacak eğitim politikalarına teorik ve pratik katkılar sunmaktır (Erdoğan, 2003, s. 1-3). Karşılaştırmalı çalışmalar sayesinde devletlerin, kültürlerin ve eğitim sistemlerinin sahip oldukları müşterek noktalar ve farklılaştıkları yönler ortaya çıkar. (Ültanır, 2000, s. 7).

Türkiye alanyazını dâhilinde İran gibi tarihte köklü bir geçmişe sahip ve sınır komşusu olan bir ülkenin eğitim sistemine ilişkin çok az sayıda çalışma (Arefi ve Alizadeh, 2008; 
Aşık, 2006; Karakul, 2014; Kendirci, 2006; Nadim, 1996; Owen, Damırchı ve Molaei, 2013; Tamer, 2010) bulunmaktadır. Bugüne kadar İran eğitim sisteminin bütününe yönelik kapsamlı bir çalışma yapılmamıştır. Yapılan çalışmalar iki ülkenin eğitim sistemini karşılaştırmaya dönük belli bir boşluğu doldursa da yeterli değildir. Yapılan çalışmalarda "İran eğitim sisteminin modernleşme süreci”, "İran'da ders kitaplarında yurttaşlık eğitimi”, “İran ders kitaplarında Türk ve Türklük imajı”, “İran'da PDR alanı”, "İran'da iki dillilik" ve "İran’da eğitim finansmanı" gibi genelde İran eğitim sisteminin dar bir boyutu ele alınmıştır.

Nadim (1996), çalışmasında İran eğitim sistemine dönük tarihi bilgiler eşliğinde bugünkü duruma dikkat çekmektedir. İslam devrimi öncesi ve sonrası kültür ve eğitim alanındaki değişimleri ele aldığı çalışmasında Tamer (2010), İran eğitim sisteminde gerçekleştirilen reform çalışmalarını incelemiştir. Aşık'ın (2006) çalışmasında, İran'daki eğitim-din-devlet kurumları arasındaki ideoloji temelli, beklenmeyen sonuçlara yol açan, karmaşık ve düzensiz ilişkiler ön plana çıkmaktadır. Kendirci (2006), "İran’daki İlkokul Ders Kitaplarında Din ve Yurttaşlık” adlı çalışmasında İran'ın devrimden sonra yeni rejimin hayatın her alanını İslamileştirme çabası içinde olduğunu, öncelikli hedefin yeni bir meşruiyet yaratmak ve yeni siyasi rejimin ihtiyaçları doğrultusunda rejime sadık yurttaşlar yetiştirmek olduğunu vurgular. Korkut-Owen, Damırchı ve Molaei’nin (2013) yaptıkları çalışmada Türkiye ve İran'da Psikolojik Danışmanlık Rehberlik alanında iki ülkenin de diğerine göre daha iyi olduğu yönlere dikkat çekilmiştir. Arefi ve Alizadeh (2008) İran'da iki dillilik konulu çalışmalarında, İran toplumunda iki dilli çocukların Farsçayı öğrenmede başarılı olsalar da, anadilleri eğitim kurumlarında desteklenmediği için iki dillilik süreçlerinin sınırlı kaldığı sonucuna varmışlardır. Karakul (2014), İran ve Türkiye'de eğitim finansmanlarını karşılaştırdığı çalışmasında eğitim hakkının kullanılabilmesini güvence altına almak açısından İran'ın Türkiye'den daha iyi bir durumda olduğunu vurgulamaktadır.

Bu çalışmalardan da anlaşılacağı üzere iki ülke eğitim sistemlerine dönük karşılaştırmalı yaklaşımları içeren araştırmaların bilimsel ölçütlere göre gerçekleştirilmesi, ülkelerin eğitim politikalarının belirlenmesi sürecine katkı sağlamaktadır. Türkiye ve İran, farklı siyasal rejimlerle yönetiliyor olmalarına rağmen, eğitim sistemlerinin yapısında ve amaçlarında benzerlikler söz konusudur. Ancak her iki eğitim sistemi, siyasal ve ideolojik açıdan farklı insan modelini hedeflese de kendi toplumlarının çok kültürlü, çok kimlikli ve çok inançlı yapısını gözden rrak tutarak siyasal sitemin üzerine oturduğu ideolojiye uygun tek tip insan modeli yetiştirmeyi amaçlamaları bakımından ortak hedeflere sahiptir. Bu benzerlikleri hem hedeflenen insan modelinde hem de eğitim sistemlerinin iç unsurlarında gözlemlemek mümkündür.

Türkiye'nin ilişki içinde olduğu ülkeler birçok açıdan çeşitlilik ve farklılık arz etmektedir. $\mathrm{Bu}$ ülkelerin bulunduğu coğrafya, ait olduğu medeniyet, kültür ve tarih birbirinden çok farklıdır. Türki Cumhuriyetler, Ortadoğu ülkeleri, Balkan ülkeleri, Avrupa Birliği, Rusya, ABD vd. bu anlamda örnek olarak söz konusu edilebilir. Son yıllarda Türkiye'nin bu ülkelerle öğrenci hareketliliğinde de artış söz konusudur. Buna rağmen yoğun ilişki içinde olunan bu ülkelerin birçoğunun eğitim sistemleri yeterince tanınmamaktadır. İran da eğitim sistemi hakkında yeterince bilgi sahibi olmadığımız ülkelerden biridir. Bütün bunlar karşılaştırmalı eğitim çalışmalarının önemini ve gerekliliğini ortaya koymaktadır. $\mathrm{Bu}$ araştırmanın amacı, Türkiye ve İran eğitim sistemlerinin amaçları arasındaki 
benzerlikleri ve farkl11ıkları tespit ve analiz etmektir. Bu problem durumuna bağlı olarak alt problemler şunlardır:

(i) İran ve Türkiye eğitim sistemlerinin genel amaçları, özel amaçları ve ilkeleri nelerdir?

(ii) İran ve Türkiye eğitim sistemlerinin genel amaçları, özel amaçları ve ilkelerinin benzerlikleri ve farklılıkları nelerdir?

\section{YÖNTEM}

$\mathrm{Bu}$ çalışma temelde bir karşılaştırmalı eğitim araştırmasıdır. Eğitim sistemlerinin karşılaştırılmasında "yatay" ve "dikey" olmak üzere iki yaklaşım söz konusudur. Yatay yaklaşım modelinde eğitim sistemlerinin ayrı ayrı ve birlikte bütün unsurları ve yönleri incelenir. Başka bir deyişle, yatay yaklaşımda eğitim sistemleri arasındaki farklılıkları tespit etmek için eğitim sistemlerinin tüm unsurları, söz konusu döneme ait tüm değişkenlerle beraber yan yana konarak incelenir. Bu bağlamda sorunlar aynı döneme ait ve dolayısıyla çağdaş olduğu için çözümler de benzer olabilir. Dikey yaklaşım modelinde ise tarihsel gelişim takip edilir. Böylece dikey yaklaşım, karşılaştırmalı eğitim alanında çalışan eğitimcinin geleceğe dönük öngörüde de bulunmasını sağlar (Ültanır, 2000: 24). İran ve Türkiye eğitim sistemlerinin amaçlarının karşılaştırıldığ yaklaşım benimsenmiştir.

$\mathrm{Bu}$ araştırma aynı zamanda bir betimsel taramadır. Betimsel model (tarama modeli) geçmişte ya da halen var olan bir durumu var olduğu şekliyle betimlemeyi amaçlayan araştırma yaklaşımıdır. Bu tür araştırmalarda, ele alınan olaylar ve durumlar ayrıntılı bir biçimde araştırılmaktadır (Erkuş, 2005). Araştırmacı İran eğitim sisteminin amaçlarıyla ilgili dokümanlara ve verilere doğrudan orijinal Farsça metinlerden ulaşma yoluna gitmiştir. $\mathrm{Bu}$ yönüyle araştırma aynı zamanda belge/doküman analizine dayanan nitel bir çalışmadır. Zira doküman analizi yöntemi, araştırmanın amacına yönelik kaynaklara ulaşmada ve elde edilecek verilerin tespit edilmesinde kullanılan, çalışılacak konularla ilgili olarak yazılı ve basılı belgelerin analizini içerir (Çepni, 2007; Yıldırım ve Şimşek, 2006). Duverger'in (1973) "belgesel gözlem" diye adlandırdığı bu yöntemi, Rummel (1968) ve birçok araştırmacı "doküman metodu" olarak adlandırmışlardır. Best (1959) ise bu yöntemi "mevcut kayıt ya da belgelerin, veri kaynağı olarak, sistemli incelenmesi" olarak tanımlamıştır (Karasar, 2007'den aktaran: Yalçınkaya ve Özkan, 2012). Metin içinde yer alan köşeli parantezler ilgili kavramları açıklamak amacıyla yazarın kendisi tarafından eklenmiştir.

\subsection{Veri Toplama Süreci ve Verilerin Çözümlenmesi}

$\mathrm{Bu}$ çalışmanın ilk aşamasında doküman analizi ve belge incelemesi çerçevesinde araştırma için gerekli veriler toplanmıştır. Araştırmada Türkiye ve İran eğitim sistemlerinin amaçlarının konu edildiği ilgili kanunlardan, yönetmeliklerden, mevzuatlardan, tezlerden, kitaplardan, makalelerden, bakanlıkların ve kurumların yayınlarından ve web sitelerinden yararlanılmıştır. Ayrıca İran Eğitim Öğretim Bakanlığı, Bilim Araştırma ve Teknoloji Bakanlığı ve Ankara'daki İran okulunda çalışan yetkililerle birebir görüşme ve yazışmalar aracıllğıyla birtakım bilgiler elde edilmiştir. Çalışmada 
ulaşılan Farsça kaynaklar araştırmacının kendisi tarafından Türkçeye çevrilmiştir. Elde edilen veriler karşılaştırmalı eğitimde doküman analizine uygun olarak benzerlikler ve farklılıklar açısından ele alınmış, nitel karşılaştırmalar yapılmış, ardından elde edilen sonuçlar yorumlanmıştır.

\section{BULGULAR}

\section{1. İ̉an Eğitim Sisteminin Genel Amaçları}

İran eğitim sisteminin genel amaçları 1998 626. Eğitim-Öğretim Yüksek Şurasında belirlenmiştir. Aşağıda detaylı olarak aktarılan İran eğitim sisteminin genel ve özel amaçları Edhem'in (2013). "Eğitim Öğretim Bakanlığı Araştırma ve Planlama Kurumu/Eğitim-Öğretim Yüksek Şurası Onaylanmış Bazı Kanunlar” adlı kitabından başlıklarıyla birlikte aynen tercüme edilmiştir:

İran eğitim sisteminin genel amaçları “İslam'ın eğitim-öğretim sisteminde nihai hedef, insanın Allah'a yaklaşmasıdır." cümlesi ile başlar ve aşağıdaki sekiz alt başlıkta maddeler halinde siralanır

\subsection{1. İnançsal Amaçlar}

(i) İnsanın kendisini ve Allah'ı tanımak için uygun şartları oluşturmak ve hakikati arama çabasını güçlü kılmak.

(ii) Kur'an-1 Kerim, peygamberin sünneti ve masum imamlar inanc1 temelinde, anayasanın on iki ve on üçüncü maddesinde yer alan İslami mezhepler ve dini azınlıklar ilkesine riayet ederek imanı, İslam inancına bağlılığ güçlendirmek ve ilahi bir bakış açısı kazandırmak.

(iii) Allah'ın, dünya ve insan üzerinde mutlak hâkimiyet sahibi olduğunu kabul eden bir kişilik inşa etmek ve bu hâkimiyeti toplum üzerinde Velayeti Fakih öğretisi doğrultusunda tatbik etmek.

\subsubsection{Ahlaki Amaçlar}

(i) Allah'a iman ve İslami takva temelinde benliği arındırmak ve ahlaki erdemliliği geliştirmek.

(ii) Allah'a kulluk temelinde bir kişilik inşası ve İslami hüküm ve kurallara bağlılık.

(iii) Öz yeterliliğe ve özgüvene sahip bir kişilik yetiştirmek.

(iv) Onurlu ve kişilik sahibi bireyler yetiştirmek.

(v) Barışçıl yaşam tarzını ve insani ilişkileri benimseyen bir kişilik yetiştirmek.

(vi) Düzen ve disiplin sahibi bireyler yetiştirmek.

(vii) Başıboşluk, tembellik ve boş uğraşlarla mücadele eden bireyler yetiştirmek.

\subsubsection{Bilimsel-Eğitsel Amaçlar}

(i) Araştıran, düşünen, soruşturan, eleştiren ve üreten bireyler yetiştirmek.

(ii) Eğitim, öğretim ve yetiştirmenin sürekliğine inanan bireyler yetiştirmek. 
(iii) Bireylerin ve toplumun gelişimini sağlamak amacıyla bireyin yeteneklerini keşfetmek ve bireyi o yönde yetiştirip yönlendirmek.

(iv) Bilimi, bilgiyi ve beşeri kazanımları/tecrübeleri daha ileri taşımak amacıyla yaratılış dünyasının ve doğa kanunlarının gizemlerini Allah'ın ayetleri olarak tanımak ve keşfetmek.

(v) Fars dili ve alfabesini İran halkının ortak resmi dili olarak yaygınlaştırmak ve Kur'an'a, İslami ilimlere aşinalık kazandırmak amacıyla Arapçayı öğretmek.

(vi) Bilimi, teknolojiyi geliştirmek; bireyi ve toplumu yetenekleri doğrultusunda geliştirmek.

(vii) Kitap okuyan ve mütalaa eden bir kişilik yetiştirmek.

(viii) Örgütlü çalışmalarda dayanışma ve katılım sağlayan bireyler yetiştirmek.

\subsubsection{Kültürel ve Sanatsal Amaçlar}

(i) Çeşitli sanatsal ve estetik ilgileri, yetenekleri keşfetmek, geliştirmek ve yönlendirmek.

(ii) Yaratılış dünyasının güzelliklerini ilahi güzelliklerin bir yansıması olarak tanımak/keşfetmek.

(iii) İslami sanatları, milli sanatları ve uygun evrensel sanatları tanımak.

(iv) Kültürel, sanatsal ve tarihi mirası koruma bilincine sahip bireyler yetiştirmek.

(v) Fars edebiyatını sanatsal zevkin bir yansıması ve ülkenin milli, toplumsal birliğinin bir göstergesi olarak tanımak.

(vi) İran İslam toplumunun uygun kültür, adap ve geleneklerini tanımak.

(vii) Uygunsuz geleneklerden ve hurafelerden uzak güçlü iradeye sahip bireyler yetiştirmek.

(viii) İslam'ın, İran'ın ve dünyanın tarihini, kültürünü, medeniyetini tanımak ve modern kültüre yoğunlaşmak.

\subsubsection{Toplumsal Amaçlar}

(i) İslam ahlakına ve hukuka dayalı aile ilişkilerini önemseyen ve buna saygı duyan bireyler yetiştirmek.

(ii) İslam adaletinin gerçekleşmesini sağlayacak ve buna saygı duyacak bireyler yetiştirmek.

(iii) Kardeşlik duyguları, İslami dayanışması, milli ve kültürel birlik anlayışı güçlü bireyler yetiştirmek.

(iv) Toplumun tüm bireylerinin bir sorumluluğu olarak "iyiliği emretme ve kötülükten sakındırma” bilincine sahip bireyler yetiştirmek.

(v) Kanunlara riayet eden ve saygılı olan bireyler yetiştirmek.

(vi) Bireysel ve toplumsal ilişkilerde düzenli olan bireyler yetiştirmek.

(vii) Dini, kültürel, sosyal faaliyetlere katılan ve sorumluluk üstlenen bireyler yetiştirmek.

(viii) Tevellâ (12 İmam inancı) ve teberrâ (12 İmamın düşmanlarından beri olmak) ruhunu güçlendirmek.

(ix) Toplumsal ilişkilerde fedakârlık, feragat ve isâr sahibi (başkasını kendisine önceleyen) bireyler yetiştirmek. 
(x) Düşünsel tartışmalarda başkalarına tahammül eden, saygı duyan ve hoşgörülü davranan bireyler yetiştirmek.

(xi) İnsanların onur ve şahsiyetlerine saygı gösteren ve maddi-manevi haklarına riayet eden bireyler yetiştirmek.

(xii) Olumsuz propagandalara karşı direniş gösterebilen bireyler yetiştirmek.

\subsubsection{Yaşamsal ve Çevresel Amaçlar}

(i) Gerekli, uygun şartları hazırlayarak bireylerin bedensel ve ruhsal sağlı̆̆ını temin etmek.

(ii) Genel sağlığa ve çevre temizliğine riayet eden bireyler yetiştirmek.

(iii) İnsanın manevi gelişimi için gerekli olan beden eğitimi ve sağlığı bilincine sahip bireyler yetiştirmek.

\subsubsection{Siyasi Amaçlar}

(i) Ülkenin siyasi geleceğine çeşitli alanlarda katkı sunmak amacıyla Velayeti Fakih düşüncesi temelinde siyasi bilinci yükseltmek.

(ii) Müslümanlar arasında İslami birlik düşüncesini yeşertmek. Yeryüzünde haksızlığa ve adaletsizliğe uğrayanlar, mazlumlar ve ezilenler için mücadele etmek. İslami değerler temelinde egemenler, sömürgeciler ve zalimlerle mücadele etmek.

(iii) Ülkenin her açıdan bağımsızlığını destekleyen ve ülkeye yönelik her türlü baskı, sömürü ve dayatmayı reddeden bireyler yetiştirmek.

(iv) İslam inancını ve bu doğrultuda ülkenin direnme gücünü koruyacak mücadeleci karaktere sahip bireyler yetiştirmek.

(v) İran ve dünyayla ilgili meselelere, özellikle Müslüman ülkelere ve mazlum milletlere dönük siyasi bir farkındalık oluşturmak.

(vi) Küresel, emperyalist ve egemen güçlerin hile ve oyunlarının farkında olmak ve bunlara karşı mücadele etme zorunluluğunu kavramak.

\subsection{8. İktisadi Amaçlar}

(i) Toplumsal kalkınmaya ulaşmanın bir aracı olarak iktisadi gelişmenin farkına varmak.

(ii) Çalışmanın, helal kazancın değerini ve kutsallığını kavramak.

(iii) Tarım, sanayi, hizmet sektöründe çalışmayı teşvik etmek; bu alanlarda üretimi artırmak amacıyla bireylerin yeteneklerini geliştirmek, ilgi ve alakalarını artirmak.

(iv) Her türlü lüks, israf ve gösterişten uzak sade yaşama bilincine sahip bireyler yetiştirmek.

(v) İnfak eden ve yoksulları gözeten bireyler yetiştirmek.

(vi) Ekonomik yaşamını İslami kurallara göre belirleyen ve sürdüren bireyler yetiştirmek.

(vii) Milli geliri artırmak, işsizliği, ekonomik bağımlılığı ortadan kaldırmak için bireylerde mesleki eğilim ve becerileri geliştirmek. 
(viii) Ekonomik sömürü, rant, yolsuzluk ve İslam toplumuna aykırı uygulamalara karşı mücadele eden bireyler yetiştirmek.

(ix) Ülkenin ekonomik kaynaklarını, onları doğru biçimde kullanma yöntemlerini bilen; kamu malını ve milli serveti koruma bilincine sahip bireyler yetiştirmek (Edhem, 2013).

\section{2. Özel Amaçlar}

İran eğitim sisteminde özel amaçlar, genel amaçların her bir eğitim-öğretim kademesi için uyarlanmasıyla belirlenmiştir. Özel amaçlar da tıpkı genel amaçlarda olduğu gibi ayrı ayrı alt başlıklar halinde ve detaylı bir biçimde ele alınmıştır.

\subsection{Okulöncesi Kademesinin Özel Amaçları}

Okulöncesi eğitim dört yaşından altı yaşına kadar (4-5 yaş) iki yıllık bir süreyi kapsamaktadır. İmkân yetersizliğinin söz konusu olduğu durumlarda ise bu süre bir yılla sınırlı tutulabilir (İran Yüksek Eğitim-Öğretim Şurası'nın 2003'te yapılan 699. şura toplantısından). 2012 yılında İran eğitim sisteminde 6+3+3 yapısına geçildiğinden beri İran Eğitim-Öğretim Bakanlığı okulöncesi veya anasınıfı açmamaya başladı. Gerekçesi de okulöncesi eğitiminin zorunlu olmaması ve devletin bununla yükümlü olmaması şeklindeydi. Bunun dışında İran'da iki tür okulöncesi eğitimden söz edilebilir. Birincisi halkın katkısı ve girişimleriyle devlet okullarında açılan okulöncesi ve anasınıfı derslikleri; ikincisi ise ilgili kanunlar çerçevesinde özel teşebbüsler sonucu açılan anasınıfları veya okulları.

Okulöncesi eğitiminin temel ilkeleri şunlardır: Çocukların bireysel farklılıklarını göz önünde bulundurmak ve onların kültürel ve yerel şartlarına dikkat etmek. Çocukların çeşitli duyularının ve duygularının gelişim aşamalarına dikkat etmek. Oyun oynamaya ve neşeli faaliyetlere öncelik vermek, ayrıştırıcı eğitim yönteminden uzak durmak ve ilkokul kademesinin amaçlarıyla uyumluluğa dikkat etmek (Safi, 2013, s. 92). Okulöncesi eğitimin genel amaçlarını ise şu şekilde özetlemek mümkündür: Çocukların bedensel, zihinsel hareketlerini, yeteneklerini geliştirmek ve birbiriyle uyumlu kılmak. Çocukların duygularının ve özgüvenlerinin gelişimine yardım etmek. Çevreyi fark etmelerini ve doğanın güzelliklerini kavramalarını sağlamak. Grupsal faaliyetlere katılmaları için zemin hazırlamak ve bu tür faaliyetlerde mutlu olmalarını sağlamak. Yaşlarına uygun olarak bireysel ve toplumsal davranışları sergilemelerini sağlamak (Safi, 2013: 91).

Okulöncesi öğretmenlerin, bu mesleğe ilgi duyan en iyi öğretmenler arasından seçilmesi, okulöncesi öğretmenliği için aranan genel şartlar arasında yer alır. Genel şartların yanında okulöncesi öğretmenlerinin sahip olması gereken özellikler arasında neşeli bir kişiliğe sahip olmak, çok sabırlı ve tahammüllü olmak, mümkün olduğu kadar öğretmenlerin kadın adaylardan seçilmesi, okulöncesi çağındaki çocuklara ilgi duymak, özel çocuk gelişimi bölümünü önce lise düzeyinde, ardından lisans düzeyinde bitirmiş olmak, okulöncesi eğitimle ilgili yenilikleri takip etmek ve bilmek, gerekli meziyet ve maharetlere sahip olmak vd. şeklinde sıralanır (Safi, 2013, s. 92). 


\section{4. İlköğretimin Özel Amaçları}

İran eğitim sisteminde 2012 yılında yapılan değişiklikle ilkokul beş yıldan altı yıla çıkarılmıştır. İlköğretim olarak adlandırılan bu altı yıllık düzey, birinci üç yıl ve ikinci üç yıl şeklinde isimlendirilmiştir. İkinci altı yıl ise ortaöğretim düzeyi olarak tanımlanmıştır. Dolayısıyla yeni düzenlemeyle İran'da ilköğretim ifadesiyle ilk altı yıllık eğitim dönemi kastedilmektedir.

\subsubsection{Inançsal Amaçlar}

(i) Dinin usullerini bilir ve ona inanır.

(ii) Allah'ı sever ve O'nu en iyi yardımc olarak bilir.

(iii) Başta Hz. Muhammed olmak üzere Ululazm peygamberleri (Kur'an'da adı geçen 5 büyük peygamber: Hz. Nuh, Hz. İbrahim, Hz. Musa, Hz. İsa ve Hz. Muhammed) ve masum imamları belli bir düzeyde tanır ve onları sever.

(iv) Ahiretin anlamını ve insanın yaptıklarının Allah katında hesabını vereceğini bilir.

(v) Dinin, İslam'ın büyük şahsiyetlerine saygı gösterir.

(vi) Tevella (12 İmama inanmak) ve teberra (12 İmamın düşmanlarından beri olmak) kavramlarının anlamlarını bilir.

(vii) Kur'an'1 yüzünden okur, bazı sureleri ezbere bilir ve tefsirlerine aşinadır.

(viii) Bazı basit kolay hadislerin tercümesini bilir.

(ix) Namazı doğru bir biçimde kılar, namaz ve oruçla ilgili zorunlu hükümleri bilir.

(x) Farz namazları kurallarına riayet ederek kılar (kızlar için).

(xi) Haremlik selamlığ 1 bilir ve bu kurallara riayet eder.

(xii) Ergenlik dönemini, bu dönemde zaruret düzeyinde yapılması gerekenleri bilir ve uygular (kızlar için).

(xiii) Haramı-helali bilir ve ilgili hükümleri temel düzeyde yerine getirir.

(xiv) İyiliği emretme ve kötülükten sakındırmanın manasını bilir.

(xv) Allah yolunda cihat edenlere ve şehitlere saygı gösterir.

(xvi) Kutsal, önemli günleri ve mekanları bilir.

(xvii) Camiye gitmeye ilgi gösterir ve cami adabını bilir.

\subsubsection{Ahlaki Amaçlar}

(i) Doğru sözlü ve güvenilirdir.

(ii) Edepli ve merhametlidir.

(iii) Sözünde durur.

(iv) Hayâ ve iffet belirtilerine sahiptir.

(v) Büyüklere saygı göstermeyi görev telakki eder ve onların düşüncelerine önem verir.

(vi) Anne babaya itaat eder.

(vii) Cesur ve sabırlıdır.

(viii) Temizdir ve temizliği sever.

(ix) Günlük ödevlerini/sorumluluklarını kendisi yapar.

(x) Başarılı olmak için çabalar ve işini takip eder. 
(xi) İslami giyim tarzını sever ve ona uyar.

(xii) Boş zamanlarını uygun faaliyetler ve oyunlarla geçirir.

(xiii) Ümitvar ve neşelidir, sorunlarla karşılaşmaktan/mücadele etmekten çekinmez.

(xiv) Dış görünüşü düzenli ve bakımlıdır.

(xv) Başkalarının kendisine yaptı̆̆ı yanlışları ve hataları affeder.

(xvi) Başkalarıyla ilişkilerinde bir dayanağa/mantığa sahiptir.

(xvii) Başkalarıyla ilişkilerinde sevgi içerikli ve dostane kelimeler kullanır.

(xviii) Kendi işini yapmak için arkadaşlarına zahmet vermez.

(xix) Sınıf arkadaşlarına ve yaşıtlarına öğrenme faaliyetlerinde yardımcı olur.

(xx) Uygunsuz davranışları için özür diler ve davranışını düzeltir.

(xxi) Evde, okulda, toplumda düzenli, tertiplidir ve kurallara riayet eder.

\subsubsection{Bilimsel ve Ahlaki Amaçlar}

(i) Doğa olaylarına ve olgulara meraklıdır.

(ii) Düşünme, dinleme, konuşma, maksadını anlatma, okuma, yazma ve hesaplama konularında yeterli beceriye sahiptir.

(iii) Farsçaya aşinadır, Farsça kitap ve gazetelerden yararlanabilir.

(iv) Hayatta bilgi ve bilgi paylaşımının önem ve değerinin farkındadır.

(v) Ders işlerken ilmin değerinin biraz farkındadır.

(vi) Toplumda yaşamak için gerekli olan ilk becerileri kazanmıştır.

(vii) Kendi öğrenme tarzının biraz farkındadır.

(viii) Kitap okumaya ilgisi vardır.

\subsubsection{Kültürel-Sanatsal Amaçlar}

(i) Doğanın güzelliklerinin farkındadır ve doğanın uyumunu sever.

(ii) Sanatsal alanlarda doğanın güzelliklerini örnek alır.

(iii) Sanatsal eserlerini izlemekten zevk alır.

(iv) Faaliyetler esnasinda sanatsal zevkini ve becerisini ortaya koyar.

(v) Gelenekleri, doğa olaylarını ve nazım eserlerini sever.

(vi) Bazı meşhur sanat eserlerine aşinadır.

(vii) Uygun şiirleri ve hikayeleri okumaya meraklıdır.

(viii) İslam'ın ve İran'ın bazı kültürel, toplumsal gelenek göreneklerini bilir ve onlara değer verir.

\subsubsection{Toplumsal Amaçlar}

(i) Ailesine, arkadaşlarına ve komşularına karşı sorumluluklarının bilincindedir.

(ii) Aile fertlerini sever ve ev işlerinde onlara yardım eder.

(iii) Okulun öğretmenlerine ve yöneticilerine sayg1 gösterir.

(iv) Kendi hakkına razıdır ve başkalarının haklarına riayet eder.

(v) Uygun yollarla kendi hakkını elde etmek için çabalar.

(vi) Sınıf arkadaşlarını sever ve onlara yardım eder.

(vii) Başkalarıyla dayanışmayı/birlikte iş yapmayı sever.

(viii) Oyunlara ve grup faaliyetlerine katılır.

(ix) Okulun kurallarını bilir ve onlara uyar. 
(x) Toplumsal kurallara uyma konusunda hassastır.

(xi) Kendisine verilen iş ve sorumluluklara bağlıdır.

(xii) Başkalarının kendisine yönelik ıslah edici nasihatlerini/düşüncelerini kabul eder.

(xiii) Başkalarının yanlışlarını saygılı bir biçimde kendilerine ifade eder.

(xiv) Başkalarının yaptığı hizmeti takdir eder ve onlara teşekkür eder.

(xv) Konuşma adabına riayet eder.

(xvi) Ülkesine ve halkına hizmet etmeyi sever.

\subsubsection{Yaşamsal ve Çevresel Amaçlar}

(i) Kendi duyu organlarını/beden azalarını iyi korur ve onlardan yararlanır.

(ii) Otururken, yürürken ve bedensel gücünden yararlarınken doğru hareket eder.

(iii) Bireysel ve toplumsal sağlığa dikkat eder.

(iv) Çevreyi/doğayı korumak için çabalar.

(v) Uygun beden hareketleri ve oyunlarla bedensel becerisini geliştirir.

(vi) Hastalıklardan korunma yollarını bilir ve buna riayet eder.

(vii) Hastalıklardan korunmanın öneminin farkındadır.

(viii) Kendisinin ve başkalarının sağlığını korumak için çabalar.

\subsubsection{Siyasi Amaçlar}

(i) İran İslam Cumhuriyeti sistemini tanır, ülkenin bayrağına saygı gösterir ve milli marş1 ezbere okur.

(ii) İran İslam Cumhuriyeti'nin kurucusunu bilir ve onu saygıyla anar.

(iii) Toplumun gelişmesi için bağımsızlığın ve özgürlüğün öneminin farkındadır.

(iv) Dini devlet ve Velayet-i Fakih'i sever (Velayet-i Fakih: Devlet yönetimin en üst kademesinin din alimleri eliyle icra edilmesi).

(v) Müslümanları sever ve onların işlerine/sorunlarına kayıtsız kalmaz.

(vi) İran'ın çeşitli kavimlerini/halklarını tanır ve onlarla dayanışma duygusu taşır.

(vii) Adalet ve hak yolunda mücadele eden insanları sever.

(viii) İslam'ın ilk dönemindeki kâfirlerin, müşriklerin ileri gelenlerini tanır, onların Peygamber'e (as) ve Müslümanlara yaptıklarını bilir.

(ix) Günümüzde kâfirlerin ve din düşmanı müşriklerin ileri gelenlerini bilir.

(x) Milli birlik ve güven kavramına aşinadır.

\subsection{8. İktisadi Amaçlar}

(i) Çalışmayı sever ve yararlı işlerle meşgul olanlara saygı gösterir.

(ii) Kendi eşyalarını temiz ve sağlam tutar.

(iii) Tembelliğe, işsizliğe, rahatlığa alışmayı; bireyin ve toplumun yenilgilerinin sebeplerinden bilir.

(iv) Kamu mallarını milli servet bilinciyle korumaya özen gösterir ve onları yerinde kullanir.

(v) Kendi mülkiyetini başkalarının mülkiyetinden ayırt eder ve başlarının mülkiyetine sayg1 gösterir.

(vi) Yaşadığı bölgede mevcut iş ve meslek dallarını tanır.

(vii) Yerli üretim mallarını tüketmeye özen gösterir (Edhem, 2013). 


\subsection{Ortaöğretim Birinci Kademenin Özel Amaçları (Ortaokul / 7.-9. Sınıf)}

\subsubsection{Inançsal Amaçlar}

(i) Dinin usullerine inanır ve ona göre yaşar.

(ii) Rabb olduğu için Allah'ın itaate layık olduğunu bilir.

(iii) Peygamberlere (as), masum imamlara aşinalığı vardır ve onların hayatını okumayı sever.

(iv) Velayet-i Fakih anlayışına aşinadır ve onun imametle bağını bilir.

(v) Tevella ve teberra düşüncesine riayet etmeye dikkat eder.

(vi) Din büyüklerine ve İslami şahsiyetlere aşinadır ve onların hayatlarını okur.

(vii) Ahirete, ahiret gününde hesap verileceğine inanır ve yaptıklarından Allah'a karş1 sorumlu olduğunu bilir.

(viii) Namazı Allah'la irtibat kurmanın en önemli yolu görür ve beş vakit namazını kılmayı adet edinmiştir.

(ix) Kur'an'ı doğru okur ve onun bazı kıssalarını bilir.

(x) İslam tarihinin ilk dönemine aşinadır ve o döneme karşı ilgilidir.

(xi) Dinin fer'i hükümlerini bilir.

(xii) Kendi yaşına uygun bir ilmihal kitabından yararlanabilir.

(xiii) Taklit etme hükümlerini bilir ve kendisi için bir taklit mercii (yaşayan bir müçtehit, içtihat birikimine sahip bir alim) seçmiştir.

(xiv) Haremlik selamlıkla ilgili hükümlere uyar.

(xv) İyiliği emretmek ve kötülükten sakındırmak emrini yerine getirmeye ilgi duyar.

(xvi) Cihat ve şahadetin anlamını bilir, dini savunma alanlarında olmayı sever.

(xvii) Kutsal günleri ve mekânları bilir, onlara karşı sorumluluklarını yerine getirir.

(xviii) Camiye iştiyakla gider, camideki ibadet faaliyetlerine ve kültürel-sosyal etkinliklere katılır.

\subsubsection{Ahlaki Amaçlar}

(i) Doğru sözlüdür, emaneti korur ve sır saklar.

(ii) Ahlaki değerlere ilgi gösterir.

(iii) Kendi değerlerinin, gücünün farkındadır ve onları geliştirmeye çalışır.

(iv) İffetli ve hayâlı bir kız; cesur ve delikanlı bir erkektir.

(v) Anne babaya itaati görev addeder.

(vi) Kendi işini kendisi yapar ve başkalarıyla istişare etmekten kaçınmaz.

(vii) Başkalarının başarılarını takdir eder, kendisi de başarıya ulaşmak için çabalar.

(viii) Başkalarına yardımcı olur, onların zaaflarını telafi etmeye/ortadan kaldırmaya çalışır.

(ix) İslam'a ve İran kültürüne uygun giyim tarzını tercih eder.

(x) Boş vakitlerini uygun faaliyetlerle geçirir.

(xi) Diş görünüşünü dinin ve toplumun ölçülerine dikkat ederek düzenler.

(xii) Başkalarını affetme becerisi gelişmiştir.

(xiii) İnsanlarla ilişskisine dikkat ederek başkalarının kendisiyle ilgili yanlış ve hata yapma zeminini ortadan kaldırır. 
(xiv) Başkalarıyla konuşurken onlara saygı göstermesi gerektiğini bilir ve saygılı ifadelerle konuşur.

(xv) Zorunlu olmadıkça başkalarından bir şey/bir iş talep etmenin yakışık almadığını bilir.

(xvi) Kendi ülkesinin, halkının ilerlemesine, milli birlik ve beraberliğe önem ve değer verir.

(xvii) Kendisinin ve başkalarının gelişmesi için büyüklerin tecrübelerinden yararlanmayı gerekli görür.

(xviii) Bir şey yapmadan önce düşünür/tartar.

(xix) Kendisini ve başkalarını eleştirmeye önem verir.

(xx) İyiyi kötüden ayırır ve iyiliğe eğilimi vardır.

(xxi) Davranışlarında dengelidir, duygularına hâkim olmaya çalışır.

(xxii) Düzenli, tertipli olmayı adet edinmiştir.

(xxiii) Herkesin hukukunu korumak için kanuna uymayı gerekli görür.

\subsubsection{Bilimsel ve Ahlaki Amaçlar}

(i) Bilimsel, deneysel gelişmelere, doğa olaylarına karşı ilgilidir ve onların birbiriyle ilişkilerini/uyumunu fark eder.

(ii) Doğa bilimleriyle sosyal bilimler alanında gerekli bilgileri kazanmış; bu bilimlerin ve uygulamalarının toplumun gelişmesindeki rollerinin farkındadır.

(iii) Fars dili ve edebiyatıyla ilişkisi vardır, dil becerilerini kullanabilir ve basit edebi metinlerden yararlanabilir.

(iv) Matematikte temel becerileri bilir, matematiğin günlük hayattaki öneminin ve diğer bilimlerin gelişmesindeki rolünün farkındadır.

(v) Kur'an'1, hadisleri, duaları ve Fars edebiyatını daha iyi anlamak için belli düzeyde Arapçaya aşinalığı vardır.

(vi) Bir yabancı dile günlük konuşma dilinde ve basit düzeyde aşinalığı vardır.

(vii) Kitle iletişim araçlarından bilgi edinmek amacıyla yararlanabilir.

(viii) Kendi toplumunu ve yaptıkları işleri belli düzeyde tanır ve toplumda yaşamak için gerekli becerilere sahiptir.

(ix) Çalışma yöntemlerini iyileştirmede/geliştirmede bilimin taşıdığı fonksiyonun farkındadır.

(x) Bilime yatkındır; mantıklı bir yapıya, eleştirel ve yaratıcı bir düşünceye sahiptir.

(xi) Kendine has öğrenme tarzının farkındadır.

(xii) Doğru bir yöntemle okumayı ve araştırmayı bilir.

(xiii) Düşünmeye ve tartışmaya ilgi duyar, bilimsel araştırma yöntemine aşinadır.

\subsubsection{Kültürel-Sanatsal Amaçlar}

(i) Kendi yeteneklerinin farkındadır ve onları geliştirmek için çabalar.

(ii) Allah'ın yarattıklarında gördüğü güzellikleri över.

(iii) Sanatsal eserleri izlemek ve araştırmaktan zevk alır.

(iv) Sanatsal yeteneklerinin farkındadır ve onları geliştirmeye çalışır.

(v) Başkalarının kültürel tecrübe ve kazanımlarından yaralanır; körü körüne taklitten sakınır.

(vi) İslam'a ve İran'a ait bazı sanat eserlerini bilir. 
(vii) Edebi ve kültürel eserleri okumaya meraklıdır.

(viii) Toplumun uygun olan kültürüne, gelenek göreneklerine aşinadır ve onlara karşı sorumluluk bilinci taşır.

(ix) İnsanın gelişimi üzerindeki etkilerinin bilincinde olarak kültür ve sanat eserlerini araştırır.

\subsubsection{Toplumsal Amaçlar}

(i) Ailesine, arkadaşlarına ve komşularına karşı sorumluluklarını yerine getirir.

(ii) Başkalarının kendisi hakkındaki ıslah edici uyarılarını/düşüncelerini araştırır ve o düşüncelerden yararlanır.

(iii) Kendisinin ve başkalarının hakkını almak için çabalar.

(iv) Çalışırken/iş yaparken başkalarından yardım alır ve başkalarına da yardım eder.

(v) Grup çalışmalarına ve toplumsal faaliyetlere katılır. Liderlik rolünün ve grup üyelerinin görevlerinin öneminin farkındadır.

(vi) Başarılı olmak için uğraşır ve başkalarının başarılarından da mutluluk duyar.

(vii) Kanunun öneminin farkındadır, ona uymayı yararlı ve zorunlu görür.

(viii) Kendi görev ve sorumluluklarının farkındadır ve onları yerine getirir.

(ix) Kendi sorumluluklarını yerine getirmeyenleri uygun bir dille uyarır.

(x) Kendi toplumunun uluslararası alanda başarılı olmasını önemser.

(xi) İsârın (başkasını kendisine önceleyen) manasını bilir ve gerektiğinde kendi hakkindan feragat eder.

(xii) Başkalarının yaptığı hizmeti takdir eder ve onlara teşekkür eder.

(xiii) Ailede ve toplumda kadın ve erkeğin rolünü/konumunu bilir.

(xiv) Halka ve ülkeye hizmet etmeyi görev addeder.

\subsubsection{Yaşamsal ve Çevresel Amaçlar}

(i) Beden azalarının fonksiyon ve görevlerini bilir ve onların birbiriyle uyumunu korur.

(ii) Bireysel, toplumsal sağlığa aşinadır ve ona uyar.

(iii) Çevreyi korumak ve yaşatmak için çabalar.

(iv) Kendi sağlığını korumak için spor yapar ve ilgisini çeken spor dalında belli bir maharete sahiptir.

(v) İlkyardım konusuna aşinalığı vardır ve gerektiğinde ilkyardım müdahalesinde bulunabilir.

(vi) Bazı hastalıkları, bulaşıcı hatalıkların sebeplerini ve onlardan korunma yollarını bilir.

(vii) Beden sağlığını korumak için beslenmenin önemini bilir ve uygun beslenmeyle kendi sağlığını korur.

\subsubsection{Siyasi Amaçlar}

(i) İslam Cumhuriyeti'ndeki yönetim silsilesini bilir.

(ii) Velayet-i Fakih'e dayalı dini yönetim sisteminin diğer yönetim sistemlerinden farkını bilir. 
(iii) Modern İran siyasi tarihine ve İslam Cumhuriyeti kurucusunun siyasi mücadelesine aşinalığı vardır.

(iv) Dünya Müslümanlarının yazgılarına/karşı karşıya kaldığı durumlara duyarlıdır.

(v) Bağımsızlığın, özgürlüğün ve bağımlılıktan kurtulmanın yollarını bilir.

(vi) Peygamberlerin ve masum imamların siyasi faaliyetleriyle hak mücadelesindeki yöntemleri hakkında bilgi sahibidir.

(vii) Mücadeleci bir ruha ve İslam ülkesini savunan bir yapıya sahiptir.

(viii) Seçimlerin ve oy kullanmanın toplum üzerindeki etkisinin/öneminin farkındadır.

(ix) İslam ülkesi düşmanlarının propagandalarına karşı uyanıktır.

(x) Milli birlik ve güvenliğin öneminin farkındadır.

(xi) Dinin ve halkın devlet üzerindeki etkisini/rolünü bilir.

\subsubsection{Iktisadi Amaçlar}

(i) Bireysel ve toplumsal gelişmeyi sağlamak için çalışmanın değerini bilir.

(ii) Kendi eşyalarını korur ve onları onararak kendilerinden azami şekilde yararlanır.

(iii) Toplumun iktisadi kalkınması için daha çok çalışmanın ve tembellikten kaçınmanın önemini bilir.

(iv) Milli, bölgesel kaynakları koruma ve geliştirme konusunda hassasiyet sahibidir.

(v) Başkalarının mülkiyet hakkına saygı gösterir ve bu hakka riayet etmede hassastır.

(vi) Bireysel, toplumsal yaşantıda iş ve mesleklerin rolünün farkındadır.

(vii) Ülkenin, yaşadığı bölgenin ekonomik kaynaklarını bilir ve onların sosyal/ toplumsal refah üzerindeki etkisinin farkındadır.

(viii) İslam'ın iktisadi hükümlerini bilir ve sorumluluğu kadar bu hükümlere uyar.

(ix) Yerli üretimi desteklemek için yerli üretim ürünlerini, benzerleri olan yabancı ürünlere tercih eder.

(x) Ekonomik girişimlere/faaliyetlere ilgi duyar (Edhem, 2013).

3.6. Ortaöğretim İkinci Kademenin Özel Amaçları (Lise / 10.-12. Sınıf)

\subsubsection{Inançsal Amaçlar}

(i) İnanç usullerine, dini temellere ve İslami hükümlere bağlıdır.

(ii) Dinlerin tekâmül seyrine aşinadır ve kendi inanç usullerini delillerle savunur.

(iii) İş yaparken Allah'a tevekkül eder ve O'na güvenerek iş yapar.

(iv) Peygamberlerle masum imamların yaşantısından haberdardır ve onların davranışlarını örnek alır.

(v) Tevella ve teberra felsefesine aşinadır; bu felsefeye uymak için özen gösterir.

(vi) Velayet-i Fakih yönetimini, kesin İslami bir hüküm olarak kabul eder ve bu konuyu delilleriyle birlikte açıklayabilecek birikime sahiptir.

(vii) Din büyüklerinin, İslami şahsiyetlerin yaşantısından haberdardır ve kendi yaşantısında onların tecrübelerinden yararlanır.

(viii) Namazı dinin direği olarak bilir ve namazını ilk vakitte kılar.

(ix) Mümkün olduğu kadar çokça Kur'an okur, bazı ayetlerin anlam ve tefsirine aşinadır.

(x) İlmihal kitabından yararlanır. 
(xi) Dünyevi ve uhrevi hayatı için planlama yapar.

(xii) Allah'a karşı sorumluluklarının bilincindedir ve sorumluluklarını yerine getirmeyi görev bilir.

(xiii) İyiliği emretme ve kötülükten sakındırma ilkesine bağlıdır.

(xiv) Cihatçı bir yapısı vardır ve şehadeti saadet bilir.

(xv) Müstehapları yerine getirmeye özen gösterir ve mekruhlardan kaçınır.

(xvi) Camiye gitmeyi, dini ve toplumsal merasimlere, törenlere katılmayı dini görev addeder.

\subsubsection{Ahlaki Amaçlar}

(i) Günahlardan ve yanlış iş yapmaktan kaçınır.

(ii) Değerleri ve değersizlikleri teşhis eder, değerli olanı takdir eder ve değerlere bağlıdır.

(iii) Kendi becerileri ve yeteneklerinden iyice yararlanır.

(iv) Kendi söylem ve eylemlerinde hayâ ve iffete riayet eder.

(v) Anne babaya itaat etmeyi vazife bilir; başkalarını da anne babalara itaat etmeye teşvik eder.

(vi) Kendi işlerini yapmak için plan/program yapar.

(vii) Allah için iyilik yapmayı ibadet sayar.

(viii) Yakışık almayan düşünceleri, davranışları kendine yakıştırmaz ve onları yapmaktan kaçınır.

(ix) İslam'a ve İran kültürüne uygun giyim tarzlarını tercih eder.

(x) Uzak görüşlülüğüyle daha iyi bir gelecek inşa eder.

(xi) Dış görünüşünde dini, toplumsal ölçülere uyar ve onları yaygınlaştırmaya özen özen gösterir.

(xii) Başkalarını güç ve imkânları ölçüsünde kabul eder; başkalarında kusur aramayı bir değersizlik olarak görür.

(xiii) Eleştiriye açık olmayı, yapıcı eleştiriyi önemli görür ve gelişmenin, ilerlemenin temeli görür.

(xiv) Başkalarına yardım etmeyi başkalarından yardım talep etmeye tercih eder, girişimci bir kişiliğe teşvik eder.

(xv) Ülkenin gelişmesi, halkının refahı için çabalar; halkın huzur ve güvenliğini birlik ve beraberliğin bir sonucu olarak görür.

(xvi) Kendi tutum, davranışlarını akli ve düşünsel bir değerlendirmeye tabi tuttuktan sonra tercih eder.

(xvii) Davranışları dengelidir ve duygularına hâkimdir.

(xviii) Kanun ve kurallara uyar; bu tutumu yaygınlaştırmak için çabalar.

\subsubsection{Bilimsel ve Ahlaki Amaçlar}

(i) Bilimsel, deneysel gelişmelere, doğa olaylarına karşı ilgilidir ve onların birbiriyle olan ilişkilerinin/uyumunun farkındadır.

(ii) Doğa bilimleriyle sosyal bilimler alanında yeterli bilgiye sahiptir ve günlük yaşamında onlardan yararlanabilir.

(iii) Farsça kitapları akıcı bir şekilde okur ve güzel Farsça konuşur.

(iv) Farsça yazım kurallarını bilir ve bu dille mektup, haber ve yazı yazabilir. 
(v) Kendisinin ve toplumun sorunlarını çözmede matematikten yararlanma becerisine sahiptir.

(vi) Bazı Kur'an surelerini, hadisleri, namaz dualarını ve sürekli okunan duaları kavrayacak kadar Arapça bilir; Fars edebiyatı metinlerini daha iyi anlamak için kendi Arapça bilgisinden yararlanır.

(vii) Başkalarıyla konuşabilecek düzeyde en az bir yabancı dile aşinadır.

(viii) Çok boyutlu ve doğru okumanın değerini bilir, yeni iletişim araçlarından yararlanma yeteneğine sahiptir.

(ix) Toplumda yaşamak, çalışmak ve daha üst kademelerde eğitim almak için gerekli beceriye sahiptir.

(x) İşleri doğru bir biçimde yapmak için rolünün farkındadır ve işlerinde teknolojiyi uygun bir şekilde kullanır.

(xi) Kendi becerisini/yeteneğini ve toplumun ihtiyaçlarını gözeterek meslek tercihinde bulunur.

(xii) Kendi öğrenme sürecinin yol haritasını çizer.

(xiii) Düşünmeye, araştırmaya ilgi duyar ve bilimsel araştırma yöntemini bilir.

\subsubsection{Kültürel-Sanatsal Amaçlar}

(i) Kendine uygun sanat dalını öğrenmek için çabalar.

(ii) İran toplumunun kültürel ve sanatsal kazanımlarını kendi milli kimliğinin bir parçası olarak görür.

(iii) Faaliyetleri esnasında sanatsal becerisini de ortaya koyar, en güzel eserleri ve anları sanatın yardımıyla kayda geçirir.

(iv) Farklı milletlerin seçkin kültürel, sanatsal eserlerinin özelliklerini tanımaya meraklıdır. Onları eleştirirken kendi ülkesiyle diğer ülkelerin kültürel tecrübe ve kazanımlarından yararlanır.

(v) Kültür ve sanat abidelerini, bu alanda şöhret kazananları tanır ve onlardan yararlanır.

(vi) İ́slam'ın, İran'ın ve dünyanın tarih, kültür ve medeniyetlerini okumaya meraklıdir.

(vii) Anadiline ve dilinin yerel/mahalli şivelerine ilgi duyar.

(viii) Sanatsal, kültürel eserleri analiz eder; başarılı kültürel ve sanatsal eserleri teşhis eder.

(ix) İranlıların düşünsel, kültürel ilişki ve birlikteliğini tesis etmek için Farsçanın öneminin farkındadır ve Fars edebiyatının seçkin eserlerine aşinadır.

\subsubsection{Toplumsal Amaçlar}

(i) Aile fertlerinin, komşularının, arkadaşlarının duygusal ve sosyal ilişkilerini geliştirmek için çabalar.

(ii) S1lairahimin (akrabaları, yakınları ziyaret etmek ve onlarla sosyal münasebetleri devam ettirmek) değerini bilir ve ailesini akraba ziyaretlerine teşvik eder.

(iii) Aile/yuva kurmanın önemini bilir ve dengeli bir ailenin özelliklerine aşinadır.

(iv) Allah'ı hak ve adaletin kaynağı olarak görür; hak ve adaletin hâkim olması için çabalar.

(v) Toplumsal barışı, birliği korumak ve yaygınlaştırmak için çabalar. 
(vi) Başkalarına karşı hayırseverdir ve onları yanlış davranışlardan sakındırır.

(vii) Toplumun maslahatını bireysel maslahatına önceler. Kanunu bireysel, grupsal eğilimlerden daha üstün görür ve ona riayet eder.

(viii) Başkalarının hakkına/hukukuna uyar ve buna bağlı kalır.

(ix) Toplumsal faaliyetlere katılma konusunda bilinçli ve ilgilidir.

(x) Bireylerin toplum içindeki sorumluluklarının bilincindedir ve bu konuda uygun davranışlar sergiler.

(xi) Başkalarının düşünce ve inançlarına karşı saygı ve tahammül duygusuyla hareket eder.

(xii) Kalkınma programlarından haberdardır ve hedeflerinin gerçekleşmesi için çabalar.

(xiii) İsârı değer olarak telakki eder ve İslam toplumunun gerektirdiği her anda kendi hakkindan feragat eder.

(xiv) Halka ve ülkeye hizmet etme yolunda gönüllü ve fedakârdır.

\subsubsection{Yaşamsal ve Çevresel Amaçlar}

(i) Beden azalarının fonksiyonlarını ve görevlerini bilir. Spor faaliyetlerine katılarak beden sağlığını ve uyumunu korur.

(ii) Bireysel, sosyal, psikolojik sağlığın, bunların toplum sağlığı üzerindeki etkisinin farkındadır ve bu konuda yapılması gerekenlere uyar.

(iii) Çevreyi koruma ve geliştirme faaliyetlerine aktif olarak katılır.

(iv) İlgi duyduğu spor dalında kendisini geliştirmek için çabalar.

(v) İlkyardım konusunda bilgi sahibidir ve gerektiğinde yaralılara yardımcı olabilir.

(vi) Bazı hastalıkların belirtilerini, onlardan korunma yollarını ve tedavi yöntemlerini bilir.

\subsubsection{Siyasi Amaçlar}

(i) İran İslam Cumhuriyeti siteminin yönetim esaslarını bilir ve ona inanır.

(ii) Dünyadaki egemen sistemleri tanır ve onları eleştirir.

(iii) Dini yönetimin ve Velayet-i Fakih sisteminin dünya ve ahiret mutluluğu üzerindeki olumlu etkisini bilir.

(iv) İran'ın ve İslam ülkelerinin siyasi coğrafyasına aşinadır; onların siyasi, kültürel ve iktisadi farklılıklarını bilir.

(v) Bağımsızlığı, özgürlüğü korumak ve başkalarına bağımlı olmamak için fedakârlıklar gösterir ve bu yolda istikrarlıdır.

(vi) Anayasaya ve onun ilkelerine aşinadır.

(vii) Mücadeleci bir yapıya sahiptir. İslam inancını ve İran'ı korumak için fedakârlık gösterir.

(viii) Modern sömürü yöntemlerinden haberdardır ve sömürüyle mücadele etme yöntemlerini bilir.

(ix) Düşmanın propaganda yöntemlerini tanır ve onlara karşı uygun tepkiler geliş̧tirir.

(x) Kamu güvenliği için toplumun birlik ve beraberliğini korumanın gerekli olduğunu bilir ve bunun için çabalar. 
(xi) Müslümanların vahdetini ve ezilenlerin kurtuluşunu sağlayacak bir zemini oluşturmak için kendisini sorumlu hisseder.

(xii) Dini, milli bir görev olarak siyasi faaliyetlerde bulunur ve siyasi meseleleri analiz eder.

(xiii) İntizarın (Mehdiyi bekleme) anlamını bilir ve gaybet döneminde (Mehdinin yokluğunda) siyasi mücadele alanındaki sorumluluklarını bilir.

\subsection{8. İktisadi Amaçlar}

(i) Çalışmayı ibadet sayar ve tembellikten kaçınır.

(ii) Eşyalarını iyi muhafaza eder, israf ve gösterişten uzak durur.

(iii) Kendi vazifesini aşkla, ilgiyle ve dikkatle takip eder; iyi ve doğru bir biçimde yerine getirir.

(iv) Ülkenin, bölgenin, dünyanın iktisadi kaynakları hakkında bilgi sahibidir ve onları geliştirmek için çabalar.

(v) Bireysel, toplumsal mülkiyet haklarını bilir ve buna riayet eder.

(vi) Kendi toplumunun üretken, meşru çalışma/meslek alanlarını bilir ve onlara ulaşmak için çabalar.

(vii) Ailenin ekonomik durumunu yükseltmek için çabalar.

(viii) İslam'ın iktisadi hükümlerini bilir ve çalışma hayatında onlara uyar.

(ix) Ülkenin ekonomik bağımsızlığını kazanma ve istikrarlı kılma yollarını bilir.

(x) Maddi kaynakları, milli serveti Allah'ın bir nimeti ve bütün nesillerin ortak malı olarak görür.

(xi) Ekonomik faaliyetlerde iktisat ilminden yararlanır.

(xii) Ülkenin ekonomik bağımsızlığını güçlendirmek için yerli üretimi yabancı üretime tercih etmekten kıvanç duyar ve yerli üretim ürünlerini kullanmaya teşvik eder.

(xiii) Ekonomik faaliyetlere katılmayı ilahi, insani ve milli bir görev addeder (Edhem, 2013).

\section{7. İ̉an Eğitim Sisteminin İlkeleri}

Okulöncesi eğitimin temel ilkeleri çocukların bireysel farklılıklarını göz önünde bulundurmak, onların kültürel ve yerel şartlarına dikkat etmek; çocukların çeşitli duyularının ve duygularının gelişim aşamalarına dikkat etmek; oyun oynamaya ve neşeli faaliyetlere öncelik vermek; ayrıştırıcı eğitim yönteminden uzak durmak ve ilkokul kademesinin amaçlarıyla uyumluluğa dikkat etmek şeklinde sayılabilir (Safi, 2013: 92).

1989 yılında İran eğitim-öğretim sisteminde yapılan reformun bir bölümü İran eğitim sisteminin ilkelerine ayrılmıştır. Bu reformla eğitim-öğretim ilkeleri 71 maddede belirlenmiştir. Bu ilkelerin başlıcaları şunlardır (Safi, 2011: 22).

Kur'an'1, sünneti ve masum imamların hayatını esas almak: İran İslam Cumhuriyeti eğitim-öğretim sistemi Kur'an, sünnet/siyer ve masum imamların hayatını temel alır.

Eğitimi öğretime öncelemek: İslami eğitim-öğretim sisteminde eğitim, öğretime öncelenmelidir ve eğitim olgusu, bütün faaliyetlerin temelinde yer almalı. 
Herkes için eğitim-öğretim: Eğitim-öğretim hizmetleri hiçbir sınıf ve tabakaya has değildir ve bütün toplumsal kesimler için olmalı.

Temel eğitim-öğretimin zorunlu olmas: Temel eğitim-öğretim zorunludur, devlet bu eğitimi gerçekleştirmek için gerekli tedbirleri hazırlamakla mükelleftir.

İmkânların adilce paylaşımı: Eğitim-öğretim sisteminde kanunlar, ilkeler, yönetmelikler ve bütçe belirlenip imkânlar dağıtılırken; sosyal adalet göz önünde bulundurulmalı, az gelişmiş bölgelere ve yoksul kesimlere öncelik tanınmalı.

Bölgesel ihtiyaçları esas almak: Eğitim-öğretim sisteminde belirlenen politikalar ve yapılan planlamalarda ülkenin muhtelif bölgelerinin iklim şartları, bölgesel ihtiyaçları, kültürel, toplumsal ve iktisadi boyutları ve bunların kalkınma programları esas alınmalı.

Büyüme aşamalarını ve ergenlik çağını dikkate almak: Eğitim-öğretim sisteminde eğitim-öğretim kademeleri, içerik ve amaçlar; büyüme ve gelişim aşamalarına uygun olmalıdır. Ergenlik döneminin ihtiyaçlarını dikkate almak özel bir öneme sahiptir.

Eğitim kademeleri ve programları arasında uyumluluk: Bütün eğitim-öğretim kademelerinde ve türlerinde (genel eğitim, fen bilimleri eğitimi, mesleki eğitim, yükseköğretim gibi) eğitim politikası ve ders programları belirlenirken içerik ve konular arasında uyumluluk esas alınmalı.

Eğitim-öğretimde her alanın özel bir değer taşıması: Derslerin politikası ve planlanması yapılırken, her alana toplumdaki karşılığı ölçüsünde değer verilmeli ve belli alanlara gereksiz değer biçmekten kaçınılmalı.

Düşünme ve üretebilme yeteneğini geliştirme: Eğitim-öğretim faaliyetlerinde öğrencilerin düşünme, analiz ve araştırma yeteneklerini geliştirecek yöntemler kullanılmalı. Öğrencilerin kendi kendine öğrenmelerini sağlayacak öğrenme ortamı hazirlanmali.

Mesleki yönlendirme: Eğitim-öğretimde mesleki ve eğitsel yönlendirmede öğrencilerin yetenekleri, ilgileri, alakaları ve çabaları esas alınmalı. Bununla birlikte mesleki alanların kapasitesi ve toplumun ihtiyaç duyduğu mesleki, teknolojik ve bilimsel alanlar göz önünde bulundurulmall.

Ayrıca yukarıda sıralanan ilkelere ek olarak İran eğitim-öğretim sisteminde şu konularla ilgili de birçok ilke belirlenmiştir: öğretmen seçimi, öğretmenlerin refah düzeyi, bilim ve tecrübeyi birleştirmek, yönetim sistemi, halkın yönetime katılması ve velilerle ilişki kurmak, sanat, spor, sağlık, özel eğitim vd. (Safi, 2011: 24).

\subsection{Türkiye Eğitim Sisteminin Amaçları}

Türkiye eğitim sisteminin genel ve özel amaçları Milli Eğitim Temel Kanununda aşağıda aktarıldığı şekliyle yer almıştır (T.C. Resmi Gazete, 1973). 


\subsubsection{Türkiye Eğitim Sisteminin Genel Amaçları}

Türkiye eğitim sisteminin genel amaçları, Milli Eğitim Temel Kanununda (Madde 2) şu şekilde yer almaktadır (T.C. Resmi Gazete, 1973):

“Türk Milli Eğitiminin genel amac1, Türk milletinin bütün fertlerini,

(i) Atatürk inkılap ve ilkelerine ve Anayasada ifadesini bulan Atatürk milliyetçiliğine bağlı; Türk Milletinin milli, ahlaki, insani, manevi ve kültürel değerlerini benimseyen, koruyan ve geliştiren; ailesini, vatanını, milletini seven ve daima yüceltmeye çalışan, insan haklarına ve Anayasanın başlangıcındaki temel ilkelere dayanan demokratik, laik ve sosyal bir hukuk Devleti olan Türkiye Cumhuriyetine karşı görev ve sorumluluklarını bilen ve bunları davranış haline getirmiş yurttaşlar olarak yetiştirmek;

(ii) Beden, zihin, ahlak, ruh ve duygu bakımlarından dengeli ve sağlıklı şekilde gelişmiş bir kişiliğge ve karaktere, hür ve bilimsel düşünme gücüne, geniş bir dünya görüşüne sahip, insan haklarına saygılı, kişilik ve teşebbüse değer veren, topluma karşı sorumluluk duyan; yapıcı, yaratıcı ve verimli kişiler olarak yetiştirmek;

(iii) İlgi, istidat ve kabiliyetlerini geliştirerek gerekli bilgi, beceri, davranışlar ve birlikte iş görme alışkanlığı kazandırmak suretiyle hayata hazırlamak ve onların, kendilerini mutlu kılacak ve toplumun mutluluğuna katkıda bulunacak bir meslek sahibi olmalarını sağlamak;

Böylece bir yandan Türk vatandaşlarının ve Türk toplumunun refah ve mutluluğunu artırmak; öte yandan milli birlik ve bütünlük içinde iktisadi, sosyal ve kültürel kalkınmayı desteklemek ve hızlandırmak ve nihayet Türk Milletini çağdaş uygarlığın yapıcı, yaratıcı, seçkin bir ortağı yapmaktır” (http://mevzuat.meb.gov.tr).

\subsubsection{Türkiye Eğitim Sisteminin Özel Amaçları}

Türkiye eğitim sisteminin özel amaçları, 1739 sayılı Milli Eğitim Temel Kanunu'nda (Madde 3) şu şekilde yer almaktadır (T.C. Resmi Gazete, 1973):

“Türk eğitim ve öğretim sistemi, bu genel amaçları gerçekleştirecek şekilde düzenlenir ve çeşitli derece ve türdeki eğitim kurumlarının özel amaçları, genel amaçlara ve aşağıda suralanan temel ilkelere uygun olarak tespit edilir."

\subsection{Türkiye Eğitim Sisteminin İlkeleri}

Türk eğitim sisteminin dayandığı temel ilkeler, Milli Eğitim Temel Kanunu'nda (Madde 4-17) yer almaktadır (T.C. Resmi Gazete, 1973):

(i) Genellik ve eşitlik: Eğitim kurumları dil, ırk, cinsiyet ve din ayırımı gözetilmeksizin herkese açıktır. Eğitimde hiçbir kişiye, aileye, zümreye veya sinıfa imtiyaz tanınamaz.

(ii) Ferdin ve toplumun ihtiyaçları: Milli eğitim hizmeti, Türk vatandaşlarının istek ve kabiliyetleri ile Türk toplumunun ihtiyaçlarına göre düzenlenir. 
(iii) Yöneltme: Fertler, eğitimleri süresince, ilgi, istidat ve kabiliyetleri ölçüsünde ve doğrultusunda çeşitli programlara veya okullara yöneltilerek yetiştirilirler.

(iv) Milli eğitim sistemi, her bakımdan, bu yöneltmeyi gerçekleştirecek biçimde düzenlenir. $\mathrm{Bu}$ amaçla, ortaöğretim kurumlarına, eğitim programlarının hedeflerine uygun düşecek şekilde hazırlık sınıfları konulabilir.

(v) Yöneltmede ve başarının ölçülmesinde rehberlik hizmetlerinden ve objektif ölçme ve değerlendirme metotlarından yararlanılır.

(vi) Eğitim hakkı: İlköğretim görmek her Türk vatandaşının hakkıdır.

(vii) İlköğretim kurumlarından sonraki eğitim kurumlarından vatandaşlar ilgi, istidat ve kabiliyetleri ölçüsünde yararlanırlar.

(viii) Fırsat ve imkân eşitliği: Eğitimde kadın, erkek herkese firsat ve imkân eşitliği sağlanır.

(ix) Maddi imkânlardan yoksun başarılı öğrencilerin en yüksek eğitim kademelerine kadar öğrenim görmelerini sağlamak amacıyla parasız yatılılık, burs, kredi ve başka yollarla gerekli yardımlar yapılır.

(x) Özel eğitime ve korunmaya muhtaç çocukları yetiştirmek için özel tedbirler alınır.

(xi) Süreklilik: Fertlerin genel ve mesleki eğitimlerinin hayat boyunca devam etmesi esastır. Gençlerin eğitimi yanında, hayata ve iş alanlarına olumlu bir şekilde uymalarına yardımcı olmak üzere, yetişkinlerin sürekli eğitimini sağlamak için gerekli tedbirleri almak da bir eğitim görevidir.

(xii) Atatürk İnkılap ve İlkeleri ve Atatürk Milliyetçiliği: Eğitim sistemimizin her derece ve türü ile ilgili ders programlarının hazırlanıp uygulanmasında ve her türlü eğitim faaliyetlerinde Atatürk inkılap ve ilkeleri ve Anayasada ifadesini bulmuş olan Atatürk milliyetçiliği temel olarak alınır. Milli ahlak ve milli kültürün bozulup yozlaşmadan kendimize has şekli ile evrensel kültür içinde korunup geliştirilmesine ve öğretilmesine önem verilir. Milli birlik ve bütünlüğün temel unsurlarından biri olarak Türk dilinin, eğitimin her kademesinde, özellikleri bozulmadan ve aşırılığa kaçılmadan öğretilmesine önem verilir; çağdaş eğitim ve bilim dili halinde zenginleşmesine çalışılır ve bu maksatla Atatürk Kültür, Dil ve Tarih Yüksek Kurumu ile işbirliği yapılarak Mili Eğitim Bakanlığınca gereken tedbirler alınır.

(xiii) Demokrasi eğitimi: Güçlü ve istikrarlı, hür ve demokratik bir toplum düzeninin gerçekleşmesi ve devamı için yurttaşların sahip olmaları gereken demokrasi bilincinin, yurt yönetimine ait bilgi, anlayış ve davranışlarla sorumluluk duygusunun ve manevi değerlere saygının, her türlü eğitim çalışmalarında öğrencilere kazandırılıp geliştirilmesine çalışılır; ancak, eğitim kurumlarında Anayasada ifadesini bulan Atatürk milliyetçiliğine aykırı siyasi ve ideolojik telkinler yapılmasına ve bu nitelikteki günlük siyasi olay ve tartışmalara karışılmasına hiçbir şekilde meydan verilmez.

(xiv) Laiklik: Türk milli eğitiminde laiklik esastır. Din kültürü ve ahlak öğretimi ilköğretim okulları ile lise ve dengi okullarda okutulan zorunlu dersler arasında yer alır. 
(xv) Bilimsellik: Her derece ve türdeki ders programları ve eğitim metotlarıyla ders araç ve gereçleri, bilimsel ve teknolojik esaslara ve yeniliklere, çevre ve ülke ihtiyaçlarına göre sürekli olarak geliştirilir. Eğitimde verimliliğin artırılması ve sürekli olarak gelişme ve yenileşmenin sağlanması bilimsel araştırma ve değerlendirmelere dayalı olarak yapılır. Bilgi ve teknoloji üretmek ve kültürümüzü geliştirmekle görevli eğitim kurumları gereğince donatılıp güçlendirilir; bu yöndeki çalışmalar maddi ve manevi bakımından teşvik edilir ve desteklenir.

(xvi) Planlılık: Milli eğitimin gelişmesi iktisadi, sosyal ve kültürel kalkınma hedeflerine uygun olarak eğitim-insan gücü-istihdam ilişkileri dikkate alınmak suretiyle, sanayileşme ve tarımda modernleşmede gerekli teknolojik gelişmeyi sağlayacak mesleki ve teknik eğitime ağırlık verecek biçimde planlanır ve gerçekleştirilir. Mesleklerin kademeleri ve her kademenin unvan, yetki ve sorumlulukları kanunla tespit edilir ve her derece ve türdeki örgün ve yaygın mesleki eğitim kurumlarının kuruluş ve programları bu kademelere uygun olarak düzenlenir. Eğitim kurumlarının yer, personel, bina, tesis ve ekleri, donatım, araç, gereç ve kapasiteleri ile ilgili standartlar önceden tespit edilir ve kurumların bu standartlara göre optimal büyüklükte kurulması ve verimli olarak işletilmesi sağlanır.

(xvii) Karma eğitim: Okullarda kız ve erkek karma eğitim yapılması esastır. Ancak eğitimin türüne, imkân ve zorunluluklara göre bazı okullar yalnızca kız veya yalnızca erkek öğrencilere ayrılabilir.

(xviii) Eğitim kampüsleri ve okul ile ailenin işbirliği: Aynı alan içinde birden fazla örgün ve/veya yaygın eğitim kurumunun bir arada bulunması halinde eğitim kampüsü kurulabilir ve bunların ortak ihtiyaçlarını karşılamak üzere eğitim kampüsü yönetimi oluşturulabilir... Eğitim kurumlarının amaçlarının gerçekleştirilmesine katkıda bulunmak için okul ile aile arasında işbirliği sağlanır. Bu amaçla okullarda okul-aile birlikleri kurulur.

(xix) Her yerde eğitim: Milli eğitimin amaçları yalnız resmi ve özel eğitim kurumlarında değil, aynı zamanda evde, çevrede, işyerlerinde, her yerde ve her firsatta gerçekleştirilmeye çalışılır. Resmi, özel ve gönüllü her kuruluşun eğitimle ilgili faaliyetleri, Milli Eğitim amaçlarına uygunluğu bakımından Milli Eğitim Bakanlığının denetimine tabidir (http://mevzuat.meb.gov.tr).

\subsection{Türkiye ve İran Eğitim Sistemlerinin Genel Amaçlarının, Özel Amaçlarının ve İlkelerinin Karşılaştırılması}

Türkiye ve İran eğitim sistemlerinin genel amaçları, özel amaçları ve ilkelerine dair ulaşılan bulgular çerçevesinde aşağıdaki benzerlikler ve farklılıklara işaret etmek mümkün. 


\subsubsection{Türkiye ve İan Ĕ̈itim Sistemlerinin Genel Amaçlar Bakımından Benzerlikleri ve Farklılıkları}

Türkiye ve İran eğitim sistemleri genel amaçlarında benzerlikler ve farklılıklar bulunmaktadır. Türkiye'nin Atatürk ilke ve inkılâpları temelinde laik/seküler bir siyasal rejime sahip olması, buna karşın İran'ın İslami ve mezhebi esaslar temelinde siyasal bir rejime dayanması eğitim sistemlerinin genel amaçlarına yansımıştır. İki ülkenin eğitim sistemleri arasındaki temel farklılığın da bu hususlarda yoğunlaştığı görülmektedir. Her iki ülkenin eğitim sistemlerinin genel amaçlarına bakıldığında milli, manevi, kültürel değerlere bağlılık; bireysel, toplumsal ve ekonomik gelişime katkıda bulunmak konusunda bir benzerliğin olduğu söylenebilir. Türkiye eğitim sisteminin genel amaçları üç maddede sıralanmış olup bireylerin Atatürk ilke ve inkılâplarına, Türk milliyetçiliğine, manevi ve kültürel değerlere, insan hakları, demokratik, laik ve sosyal bir hukuk devletine bağlılığı üzerine temellendirilmiştir. Ayrıca bireylerin kişilik ve mesleki gelişimi, toplumsal sorumluluklarına bağlılığı, sosyal ve ekonomik kalkınmayı desteklemesi vurgulanmıştır. İran eğitim sisteminin genel amaçları ise “İslam'ın eğitim-öğretim sisteminde nihai hedef insanın Allah'a yaklaşmasıdır. Bu nihai hedefe aşağıdaki amaçlarla ulaşılır." cümlesinin ardından "inançsal, ahlaki, bilimsel-eğitsel, kültürelsanatsal, toplumsal, yaşamsal-çevresel, siyasi ve iktisadi amaçlar” alt başlıkları altında maddeler halinde sıralanmıştır.

İran eğitim sisteminin Türk eğitim sisteminden farklı olarak genel amaçların belirlenmesinde bütüncül bir yaklaşım yerine, yetiştirilmek istenen insan modelini detaylı bir şekilde vasıflandırdığ 1 görülmektedir. Türkiye eğitim sisteminin genel amaçları üç maddede Atatürkçülük, ulusalcılık ve bireysel/toplumsal vurgulara sahipken; İran eğitim sisteminde Kur'an, peygamberin sünneti ve masum imamlar inancının temel teşkil etmesiyle yetinilmemiştir. Bunun yanında inançsal amaçlar temelinde "Velayet-i Fakih öğretisi doğrultusunda olma"; ahlaki amaçlar temelinde "İslami kurallara bağlılık, barışçıl yaşam tarzını benimseme"; bilimsel-eğitsel amaçlar temelinde "doğa kanunlarının gizemlerini Allah'ın ayetleri olarak tanıma ve keşfetme, kitap okuyan ve mütalaa eden bir kişilik yetiştirme”; kültürel ve sanatsal amaçlar temelinde "İslam’ın, İran'ın ve dünyanın tarihini, kültürünü, sanatını ve medeniyetini bilme"; toplumsal amaçlar temelinde "iyiliği emretme ve kötülükten sakındırma, on iki imam inancını benimseme"; siyasi amaçlar temelinde "İslam birliği düşüncesini yeşertme, yeryüzünde adaletsizliğe ve haksızlığa uğrayanlar, mazlumlar ve ezilenler için mücadele etme, İslami değerler uğruna egemenler, sömürgeciler ve zalimlerle mücadele etme, küresel emperyalist ve egemen güçlerin hile ve oyunlarının bilincinde olma"; iktisadi amaçlar temelinde "çalışmanın ve helal kazancın değerinin kutsallığını kavrama, infak ve yoksulları gözeten bireyler yetiştirme" gibi özellikler üzerinde durulmuştur.

İki ülkenin eğitim sistemlerinin genel amaçları arasındaki en belirgin farklılık Türkiye'nin Atatürk ilke ve inkılâplarına bağlı laik bir yapıya, İran'ın ise İslami ve mezhebi esaslar temelinde siyasal bir rejime sahip olmasıdır. Türkiye eğitim sisteminin genel amaçları ve ilkeleri Atatürkçülük, laiklik ve karma eğitim bakımından İran eğitim sisteminden farklıdır. İran eğitim sisteminin genel amaçları ise Kur'an, Peygamber'in sünneti, masum imamlar inanc1, Velayet-i Fakih öğretisi gibi amaçlar ve ilkeler bakımından Türkiye'den farklıdır. Her iki ülkede mevcut olan milliyetçilik, kültürel ve 
manevi değerler, bireysel ve toplumsal gelişim, herkes için eğitim, temel eğitimin zorunlu olması, bilimsellik gibi amaç ve ilkelerde benzerlik söz konusudur.

\subsubsection{Türkiye ve İran Eğitim Sistemlerinin Özel Amaçlar Bakımından Benzerlikleri ve Farklılıklarl}

İran ve Türkiye eğitim sistemlerinin özel amaçlarına bakıldığında, Türkiye'nin genel amaçlarda olduğu gibi özel amaçları da genel bir yaklaşımla ele aldığı görülmektedir. İran eğitim sisteminde ise genel amaçlarda olduğu gibi özel amaçlar da her bir eğitim-öğretim kademesi için detaylıca ele alınmıştır. Türkiye ve İran'ın siyasal rejimlerinin ve hedefledikleri insan modelinin farklı olması, eğitim sistemlerinin özel amaçlarına da yansıdığ 1 rahatlıkla söylenebilir.

Her iki ülkede okulöncesi eğitimi çocukların bireysel gelişimleri ve farklılıklarını göz önünde bulundurarak çocuklara hazırlayıcı bir eğitim sunmayı amaçlamaktadır. İlköğretim kademesine gelince, Türkiye'de ilköğretimin amaç ve görevleri üç maddede belirlenmiş olup bunlar "iyi bir vatandaş olmak", "milli ahlak anlayışına uygun olarak yetişmek" ve "öğrenciye yetenek ve kapasiteleri doğrultusunda rehberlik etmek" gibi vurgulara sahiptir. İran eğitim sisteminde ise ilköğretim ve ortaöğretim birinci kademesinin amaçları çeşitli başlıklar altında sıralanmıştır. İran eğitim sisteminde ilköğretimin amaçlarıyla ortaöğretim birinci kademesinin amaçları arasında yaşa bağlı olarak kazandırılmak istenen davranışların mahiyeti dışında kayda değer bir farklılık bulunmamaktadır.

Türkiye ve İran eğitim sistemlerinde ortaöğretim düzeyi (İran'da ortaöğretim ikinci kademe), ilköğretim düzeyine benzer amaç ve niteliklere sahiptir. Türkiye eğitim sisteminde ortaöğretimin amaç ve görevleri "bütün öğrencilere asgari düzeyde genel kültür kazandırmak; bireysel, toplumsal sorunları ve bunların çözüm yollarını göstermek; iktisadi, sosyal ve kültürel kalkınmaya katkı sağlayacak bilinci vermek" gibi vurguları içermektedir. Buna karşın İran eğitim sisteminde ortaöğretim ikinci kademenin amaçları, ilköğretim ve ortaöğretim birinci kademedeki maddeler halinde ve detaylıca sırlanmıştır.

\subsubsection{Türkiye ve İran Ĕ̈itim Sistemlerinin İlkeler Bakımından Benzerlikleri ve Farklılıkları}

Türkiye ve İran eğitim sistemlerinin dayandığı ilkeler, tıpkı genel ve özel amaçlarda olduğu gibi birtakım benzerlikler ve farklılıklara sahiptir. Türkiye ve İran eğitim sistemlerinin ilkeleri arasında doğrudan ve dolaylı ilişkiler kurmak mümkündür. Her iki ülkede temelde eğitim-öğretim süreci ve faaliyetlerinin doğal bir şekilde söz konusu olduğu bir uyumdan bahsedilebilir. Bunun yanında ilkelerin belirlenmesinde ülkelerin siyasi tercihlerinin etkili olduğu ve bunun da bazı farklılıkları barındırdığı söylenebilir. Türkiye'de daha kavramsal bir maddeleştirmenin yapıldığı, İran'da ise daha detaylı bir yaklaşımın tercih edildiği söylenebilir.

İran eğitim sisteminin belli başlı ilkeleri şunlardır: Kur'an'1, sünneti ve masum imamların hayatını esas almak, eğitimi öğretime öncelemek, herkes için eğitim öğretim, temel eğitim-öğretimin zorunlu olması, imkânların adilce paylaşımı, bölgesel ihtiyaçları esas 
almak, büyüme aşamalarını ve ergenlik çağını dikkate almak, eğitim kademeleri ve programları arasında uyumluluk, eğitim-öğretimde her alanın özel bir değer taşıması, düşünme ve üretebilme yeteneğini geliştirmek ve mesleki yönlendirme. Türkiye eğitim sisteminin ilkeleri ise genellik ve eşitlik, ferdin ve toplumun ihtiyaçları, yöneltme, eğitim hakk1, fırsat ve imkân eşitliği, süreklilik, Atatürk ilke ve inkılapları ve Atatürk milliyetçiliği, demokrasi eğitimi, laiklik, bilimsellik, planlılık, karma eğitim, eğitim kampüsleriyle okul aile işbirliği ve her yerde eğitim şeklinde sıralanmaktadır.

Türkiye eğitim sisteminin ilkelerinden olan "genellik ve eşitlik", "firsat ve imkân eşitliği" ile "eğitim hakkı" ilkeleri; eğitimin dil, rrk, cinsiyet ve din ayrımı gözetilmeksizin herkese açık ve fırsat eşitliğine dayalı olarak yürütülmesini esas almaktadır. Bu ilkeler, İran eğitim sistemindeki "herkes için eğitim öğretim" ve "imkânların adilce paylaşımı" ilkeleriyle benzerlik göstermektedir. Çünkü bu ilkeler de eğitim-öğretim hizmetlerinin hiçbir sınıf ve tabakaya özgü olmadı̆̆ı anlayışına dayanmaktadır. Ayrıca "imkânların adilce paylaşımı" ilkesi, eşitliği sağlamak adına sosyal adaleti gözetmeyi esas almaktadır. Bu sayede az gelişmiş bölgelerle yoksul kesimlerin bütçenin belirlenmesinde ve imkânların dağıtılmasında bir önceliğe sahip oldukları söylenebilir. Ancak burada her iki ülke için şu noktanın vurgulanması gerekir. Her iki ülkenin yazılı metinlerinde ve ilgili kanunlarında yer alan fırsat eşitliği, imkânların adil dağılımı ve toplumsal kesimler arasında herhangi bir ayırım gözetmemek gibi ilkelerin; pratikte karşılığını bulduğunu söylemek güçtür. Zira hem Türkiye'de hem İran'da pratikte firsat eşitsizliği, imkânların adaletsiz dağılımı ve çeşitli toplumsal kesimler arasında farklılık/ayrımcılık olduğu gözlemlenmektedir.

Türkiye eğitim sisteminin "yöneltme" ilkesiyle İran eğitim sisteminin "mesleki yönlendirme" ilkesi, öğrencilerin ilgi ve yeteneklerini göz önünde bulundurması açısından aynı çerçevede değerlendirilebilir. Bunun yanında Türkiye eğitim sisteminin "süreklilik" ilkesi, bireylerin eğitim tecrübelerinin hayat boyunca devam etmesi; "her yerde eğitim" ilkesi de eğitime mekân ve zaman sınırlaması getirilmemesi vurgusunu taşımaktadır. Türkiye eğitim sisteminde "planlılık" ilkesiyle İran eğitim sisteminde "eğitim kademeleri ve programları arasında uyumluluk" ilkeleri arasında bazı açılardan benzerlik ilişkisi kurulabilir. "planlılık" ilkesi çerçevesinde mesleki kademeler ve bunların çeşitli programları ve planlamalarının uyumuna vurgu yapılırken, "eğitim kademeleri ve programları arasında uyumluluk" ilkesinde eğitim politikaları ve ders programları arasındaki uyumluluk ön plana çıkmaktadır.

İran eğitim sisteminin ilkeleri arasında yer alan "eğitim-öğretimde her alanın özel bir değer taşıması" ilkesi, özellikle ülkenin sosyal gerçekliğinin göz önünde bulundurulmasıyla ilişkili görülmektedir. $\mathrm{Bu}$ ilke çerçevesinde alanlara "toplumdaki karşılığı ölçüsünde değer biçilmesi” gibi bir yaklaşım sergilenmektedir. Türkiye eğitim sistemindeki "laiklik", "demokrasi eğitimi" gibi ilkelere olan vurgu, İran eğitim sisteminde bu ilkeyle beraber toplumun istenilen alanlara yöneltilmesi şeklinde kendini göstermektedir.

Karma eğitim mevzusu, Türkiye'de eğitim sisteminin ilkeleri arasında yer alır. İran'da ise karma eğitim oranı okulöncesinde $\% 72$, ilköğretimde $\% 26$ 'dır. Ortaöğretimde ise İran'da karma eğitime hiç yer verilmezken yükseköğretimde karma eğitim verilmektedir. Ancak az da olsa sadece kadınlara veya sadece erkeklere eğitim veren yükseköğretim 
kurumlarının olduğunu da vurgulamak gerekir. Örneğin Tahran'da devlete bağlı EzZehra Üniversitesinde sadece kadınlara eğitim verilirken, İmam Sadık Üniversitesinde ise sadece erkeklere eğitim verilmektedir.

Türkiye eğitim sisteminin "Atatürk ilke ve inkılapları ve Atatürk milliyetçiliği", "demokrasi eğitimi" ve "laiklik" ilkelerinin, yetiştirilmek istenen insan modeli açısından İran eğitim sisteminin "Kur'an'ı, sünneti ve masum imamların hayatını esas almak" ilkesiyle yöntemsel bir benzerliğe sahip olduğu söylenebilir. Her ne kadar iki ülkenin siyasal rejimleri farklı ideolojik temellere dayansa da ortak olan yanları, eğitim sistemleri aracılığıyla dayandığı siyasal düşünceye uygun bireyler yetiştirmektir. Türkiye eğitim sistemi Atatürkçü, milliyetçi ve laik/seküler bir insan ve toplum modeli hedeflerken; İran eğitim sistemi din, milliyetçilik ve mezhep temelli bir insan ve toplum modeli hedeflemektedir. $\mathrm{Bu}$ durum, iki ülkenin dayandığ 1 siyasal rejimlerinden kaynaklanmaktadır. Benzer bir ilgiyi, Türkiye eğitim siteminin "bilimsellik" ilkesiyle İran eğitim sisteminin "eğitimi öğretime öncelemek" ilkesi arasında da kurmak mümkündür. Bu ilkeler, birbirine karşıt iki ilke gibi değerlendirilemese de Türkiye eğitim sisteminin genel olarak dayandığı seküler anlayışla İran eğitim sisteminin esas aldığı dini muhtevadan kaynaklanmaktadır. Türkiye ve İran eğitim sistemlerinde benzerliğin genel anlamda bireysel ve sosyal içerikli ilkelerde görüldüğü; farklılığın ise ideolojik ve siyasal boyutlardan kaynaklı ilkelerde görüldüğü söylenebilir. Her iki ülkede temel ilkelerin eğitim sistemlerinin ve politikalarının şekillenmesindeki rolü açıkken eğitim planlamasında kullanılan siyasal ve ideolojik dilin farklılığı dikkatlerden kaçmamaktadır.

\section{SONUÇ}

Türkiye ve İran Ortadoğu'nun iki önemli ülkesi olarak coğrafi, tarihi, kültürel, siyasi ve dini açıdan birbirine oldukça yakındır. Kuşkusuz bu yakınlığın eğitimi ve eğitim sistemlerini de kapsayan boyutu vardır. Özellikle her iki ülkenin modern dönemde benzer ve eşzamanlı olarak bir değişim dönüşüm içerisine girdikleri bilinmektedir. İran ve Türkiye'de 19. yy.'ın sonları ve 20. yy.'ın başlarından itibaren Batılılaşma hareketleri görülmüştür. Bunun da eğitim anlayışı ve eğitim sistemine ciddi anlamda yansımaları olmuştur. Batılılaşma hareketlerinin ardından ulus devlet mantığı ve seküler düşünce iki ülkede de yaygınlaşmıştır. $\mathrm{Bu}$ durum, Türkiye'de Meşrutiyet ve Cumhuriyet dönemleriyle devam etmiş ve günümüze kadar gelmiştir. İran'da ise Meşrutiyet Dönemi ve Pehlevi Hanedanlığıyla kendini göstermiş̧ir. Batılılaşma süreçleri her iki ülkede eğitim sistemlerini yapı, amaç, yönetim, finansman vb. yönlerden etkilemiştir.

İran ve Türkiye'nin eğitim sistemlerine genel olarak bakıldığında yürütülen eğitim faaliyetlerinde benzerlik ve farklılıkların olduğu gözlerden kaçmaz. Bu durum, iki ülkenin birçok ortak özelliğe sahip olmasından kaynaklanmaktadır. Genel olarak benzerliklerin coğrafi, kültürel, dini ve sosyal özelliklerle ilişkili olduğu; farklılıkların ise iki ülkenin siyasal rejimlerinden kaynaklandığı görülmektedir. 1979 yılında gerçekleşen İran İslam Devrimi'yle birlikte İran'da siyasi yönetim dini ve mezhebi bir mahiyet kazanmıştır. Türkiye'de de 12 Eylül 1980 darbesiyle birlikte ülkenin siyasal sistemi ulusalcı ve seküler anlamda daha belirgin bir hal almıştır. Her iki ülkede baş gösteren bu durum, doğal olarak eğitim sistemlerine de yansımıştır. Hatta iki ülkenin eğitim sistemleri arasındaki temel farklılığın buradan kaynaklandığı rahatlıkla söylenebilir. Ancak bu 
tarihten itibaren siyasal rejimlerin farklılığına rağmen iki ülkenin eğitim sistemleri arasında yöntemsel ve paradigmal bir benzerlikten söz edilebilir. Zira bu dönemlerden sonra siyasal rejimleri birbirinden farklı olsa da her iki ülkenin eğitim sistemleri, tek tip insan yetiştirmeyi amaç edinmiştir. İran'da bu tarihten itibaren eğitim sistemi dini, İslami, mezhebi ve milli esaslar ve yaklaşımlar doğrultusunda şekillenmiştir. Türkiye'de ise Cumhuriyetle başlayan Atatürkçü, laik ve ulusalcı eğitim anlayışı devam edegelmiştir. Bu durum, her iki ülkede ulus devlet anlayışına bağlı bir insan modeline işaret etmektedir. Aradaki fark İran'da dini, mezhebi ve milli; Türkiye'de ise laik, seküler ve milli bir anlayışın temel alınmasıdır. Yukarıda da ifade edildiği gibi her iki ülkenin siyasi rejimlerinden kaynaklanan eğitim sistemlerindeki bu temel fark, tek tip insan yetiştirmeyi hedeflemeleri bakımından oldukça benzerdir.

Ülkelerin eğitim anlayışına etki eden siyasal ve sosyal farklılıklar, eğitim politikalarının gözlenmesi açısından önemli bir durum oluşturmaktadır. Özellikle dini, mezhebi ve milli gerekçelerin ön plana çıktığı İran gibi bir ülkeyle; Atatürkçülük, laiklik/sekülerlik ve milliyetçilik düşüncesi ekseninde şekillenen Türkiye'nin eğitim sistemlerinin karşılaştırılması bu açıdan oldukça önem arz etmektedir.

\section{KAYNAKÇA}

Arefi M., \& Alizadeh S. (2008). İkidilliliğin Bilişsel Gelişime Olan Etkileri: İran'daki İkidilli Çocukların Örneği, Hacettepe Üniversitesi Eğitim Fakültesi Dergisi (H. U. Journal of Education). 34, 12-18.

Aşık, M. O. (2006). 1851 Yılından Günümüze İran Eğitim Sisteminin Beklenmeyen Sonuçları. Sosyoloji Dergisi, 16, 136-138.

Çepni, S. (2007). Araştırma ve Proje Çalışmalarına Giriş (3.Baskı). Ankara: Pegem A Yayıncılık.

Edhem, M. N. (2013). Sazman Pajuhash ve Barnamerizi Vazarat Amozash ve Parvararish (Ĕgitim Öğretim Bakanlı̆̆ Araştırma ve Planlama Kurumu), Macmoaye Mosavvabat-i Shuraye Aliye Amozash ve Parvarish (Ĕ̈itim-Öğretim Yüksek Şurası Onaylanmış Bazı Kanunlar) Tahran: İntisharat Madrasa.

Erdoğan, İ. (2003). Karşılaştırmalı Eğitim: Türk Eğitim Bilimleri Çalışma Alanları İçinde Önemsenmesi Gereken Bir Alan, Türk Ĕgitim Bilimleri Dergisi, cilt 1, sayı 3.

Erkuş, A. (2005). Bilimsel Araştırma Sarmalı. Ankara: Seçkin.

Karakul, A. K. (2014). İran ve Türkiye'de Eğitim Finansmanının Karşılaştırılması, Mehmet Akif Ersoy Üniversitesi Eğitim Fakültesi Dergisi, S 31, 67-87.

Karasar, N. (2003). Bilimsel Araştırma Yöntemleri. Ankara: Nobel.

Kendirci, G. (2006). Iran İlkokul Ders Kitaplarında Din ve Yurttaşlık. Yüksek Lisans Tezi. İstanbul: Yıldız Teknik Üniversitesi. 
Korkut-Owen, F., Sadri Damirchi, E., \& Molaei, B. (2013). İki Orta Doğu Ülkesinde Psikolojik Danışma ve Rehberlik Alanı: Türkiye ve İran. Uludă̆ Üniversitesi Ĕ̌itim Fakültesi Dergisi, 26(1), 81-103.

Nadim, P. (1996). İran Eğitim Sistemi: Bir Değerlendirme. Marmara Üniversitesi Atatürk Eğitim Fakültesi Eğitim Bilimleri Dergisi, 8, 153-165.

Safi, A. (2011). Amozesh ve Pervereish Ibtidai Rahnemaye Tahsili ve Motavassite. Tahran: Samt.

Safi, A. (2013). Sazman ve Kavanine Amozash ve Parvarishe Iran. Tahran: Samt.

T.C. Resmi Gazete (1973). Milli Eğitim Temel Kanunu, 14574, RG. 24/6/1973, KN. 1739, KT. 14/6/1973.

Tamer, Y.(2010). Basic changes in the Iranian Education System before and after Islamic Revolution / İslam Devrimi Öncesi ve Sonrası İran Eğitim Sistemi'nde Temel Değişimler. Yüksek Lisans Tezi. Ankara: Orta Doğu Teknik Üniversitesi.

Ültanır, G. (2000). Karşılaştırmalı Eğitim Bilimi-Kuram ve Teknikler. Ankara: Eylül.

Yalçınkaya, Y., \& Özkan, H. H. (2012). 2000-2011 Yılları Arasında Eğitim Fakülteleri Dergilerinde Yayımlanan Matematik Öğretimi Alternatif Yöntemleri İle İlgili Makalelerin İçerik Analizi. Süleyman Demirel Üniversitesi Sosyal Bilimler Enstitüsü Dergisi, 16(2), 31-45.

Yıldırım, A., \& Şimşek, H. (2008). Sosyal Bilimlerde Nitel Araştırma Yöntemleri. Ankara: Seçkin. 